\title{
Ulcerative colitis in the Chinese population of Vancouver, British Columbia
}

\author{
HuGH CHAUN BM FRCP FRCPC, HuGH J FREEMAN MD FRCPC FACP
}

H CHAUN, HJ FREEMAN. Ulcerative colitis in the Chinese population of Vancouver, British Columbia. Can J Gastroenterol 1994;8(5):303-307. The clinical records of 22 Chinese patients with ulcerative colitis (UC) seen in Vancouver, British Columbia from 1975 to 1989 were reviewed. There was a predominance of males, with a male to female ratio of $1.75: 1$. The age range at diagnosis was 14 to 67 years (mean 38.9). Eighteen of the 22 patients were immigrants, and one was a visitor from Hong Kong. The age at diagnosis of the three Canadian-born patients $(14,26$ and 26 years old) was less than the mean age at diagnosis of the immigrant group. The immigrants had resided in Canada for a mean of 9.3 years before developing symptoms of UC. Despite the rarity of UC in Hong Kong, 59\% of the Chinese patients in this series were Hong Kong immigrants. This study demonstrates that UC is not as uncommon a disease in Chinese as had been previously perceived. Adequate time is apparently necessary for exposure to environmental factors in the pathogenesis of UC. The opportunity for continued study of defined ethnic immigrant populations in North America may yield useful information related to environmental factors that may be important in the etiology and pathogenesis of UC.

Key Words: Chinese, Epidemiology, Inflammatory bowel disease, Ulcerative colitis

\section{Colite ulcéreuse dans la population chinoise de Vancouver, en}

\section{Colombie-Britannique}

RÉSUMÉ : Les dossiers cliniques de 22 patients chinois porteurs de colite ulcéreuse (CU) observés à Vancouver en Colombie-Britannique entre 1975 et 1989 ont été passés en revue. On a noté une prédominance des hommes, le ratio homme-femme étant de 1,75:1. Au moment du diagnostic, l'âge variait de 14 à 67 ans (moyenne 38,9). Dix-huit patients sur 22 étaient des immigrants, l'un était un visiteur de Hong-Kong. L'âge, au moment du diagnostic, chez trois patients nés au Canada $(14,26$ et 26$)$ était inférieur à l'âge moyen du groupe d'immigrants au moment du diagnostic. Les immigrants avaient résidé au Canada en moyenne 9,3 ans avant l'installation des symptômes de CU. Malgré la rareté de la CU à Hong-Kong, $59 \%$ des patients chinois de cette série étaient originaires de continuer à la page prochaine

Department of Medicine (Gastroenterology), University Hospital and University of British Columbia, Vancouver, British Columbia

Correspondence and reprints: Dr H Chaun, \#601-805 West Broadway, Vancouver, British Columbia V5Z 1K1. Telephone (604) 872-0717

Received for publication December 8, 1993. Accepted February 14, 1994
U LCERATIVE COLITIS (UC) IS GEN. erally assumed to be uncommon in the Chinese. This is suggested by a number of publications. A report from Singapore in 1971 (1) was probably the first literature description of UC in the Chinese. UC was found in only $18 \mathrm{Chi}$ nese patients in Hong Kong from 1951 to 1980 (2). There was another review of 23 cases of UC occurring in Hong Kong Chinese between 1986 and 1991 (3). The annual incidence rate of UC in Hong Kong from 1966 to 1980 was estimated to be around 1 per $1,000,000$ (2). There were two Chinese among 10 Malaysian patients with UC in Kuala Lumpur during a 10-year period to 1977 (4). Five of 23 cases of UC in the same city from 1982 to 1987 were Chinese (5); at that time, $53 \%$ of the population of Kuala Lumpur were Chinese. UC also appears to be rare in Singapore, with an estimated incidence of 0.02 per 100,000 and prevalence of 2 per 100,000 in 1971 (1), and a possible prevalence of 8.6 per 100,000 in 1992 (6). In 1974, the population in Singapore was about $2,000,000$ of whom $75 \%$ were Chinese (7). Sixty-nine per cent of 61 cases of UC in Singapore seen between 1971 and 1986 were Chinese (8), and 28 of 40 patients $(70 \%)$ in the same city seen between 1981 and 1990 were Chinese (6). UC has been observed in China (9). In the United States, Mendeloff noted seven cases of inflammatory bowel disease in Chinese 
Hong-Kong. Cette étude démontre que la CU n'est pas une maladie si rare dans la population chinoise, contrairement à ce que l'on avait pensé jusqu'alors. Il faut apparemment suffisamment de temps d'exposition à des facteurs environnementaux avant d'observer la pathogenèse de la CU. La possibilité de poursuivre l'étude de cette population immigrante nord-américaine bien circonscrite pourrait être une source de renseignements utiles sur les facteurs environnementaux, possiblement incriminés dans l'étiologie et la pathogenèse de la cu.

\section{TABLE 1}

Epidemiological data

\begin{tabular}{|c|c|c|c|c|c|}
\hline $\begin{array}{l}\text { Patient } \\
\text { (sex) }\end{array}$ & $\begin{array}{c}\text { Age } \\
\text { at } \\
\text { diagnosis }\end{array}$ & Birth place & $\begin{array}{c}\text { Country of } \\
\text { origin }\end{array}$ & $\begin{array}{l}\text { Time to symptom } \\
\text { onset after arrival } \\
\text { in Canada (years) }\end{array}$ & $\begin{array}{l}\text { Time to diagnosis } \\
\text { after arrival in } \\
\text { Canada (years) }\end{array}$ \\
\hline $1(\mathrm{M})$ & 35 & Hong Kong & Hong Kong & 3 & 7 \\
\hline $2(M)$ & 56 & China & Hong Kong & 32 & 32 \\
\hline $3(M)$ & 29 & Hong Kong & Hong Kong & 13 & 15 \\
\hline $4(M)$ & 25 & Guangzhou $^{\dagger}$ & Hong Kong & 12 & 12 \\
\hline $5(M)$ & 28 & Guangzhou $^{\dagger}$ & Hong Kong & 8 & 8 \\
\hline $6(F)$ & 61 & $\begin{array}{l}\text { Guangdong } \\
\text { province }^{\dagger}\end{array}$ & Hong Kong & 3 & 3 \\
\hline $7^{*}(\mathrm{~F})$ & 37 & Hong Kong & Hong Kong & 18 & 20 \\
\hline $8(M)$ & 52 & Hong Kong & Hong Kong & $0^{\dagger}$ & $0^{\dagger}$ \\
\hline $9(F)$ & 28 & Hong Kong & Hong Kong & 5 & 7 \\
\hline $10(\mathrm{M})$ & 46 & China & Hong Kong & 8 & 9 \\
\hline $11(\mathrm{M})$ & 52 & Guangzhou $^{\dagger}$ & Hong Kong & 0 & 0.3 \\
\hline $12(\mathrm{M})$ & 28 & Hong Kong & Hong Kong & 5 & 7 \\
\hline $13(\mathrm{M})$ & 52 & Beijing $^{\dagger}$ & Taiwan & 0 & 0 \\
\hline $14(F)$ & 37 & Hong Kong & England & 8 & 10 \\
\hline $15(F)$ & 31 & Hong Kong & Hong Kong & 5 & 5 \\
\hline $16(F)$ & 28 & Guangzhou $^{\dagger}$ & China & 0.5 & 0.5 \\
\hline $17(F)$ & 14 & Vancouver & Canada & - & - \\
\hline $18(M)$ & 26 & Vancouver & Canada & - & - \\
\hline $19(\mathrm{M})$ & 59 & Hong Kong & Hong Kong & 4 & 11 \\
\hline $20(M)$ & 26 & Canada & Canada & - & - \\
\hline $21(F)$ & 67 & China & India & 18 & 18 \\
\hline $22(M)$ & 39 & China & China & 25 & 25 \\
\hline
\end{tabular}

"Father is Portuguese, mother is Chinese: ${ }^{\dagger}$ In China: ${ }^{\dagger}$ Visitor from Hong Kong

(10). In 1989, we first presented data on UC occurring in Chinese patients in Vancouver, British Columbia (11). Although it was previously recognized that studies of Asian migrants to Hawaii and/or California would be useful in the investigation of environmental determinants of inflammatory bowel disease (12), there has been no further information on UC in the Chinese populations of North America.

Vancouver has a population of approximately 2,000,000. The Chinese population in 1986 was 100,340 (13), and there were an additional 13,547 Chinese immigrants to British Columbia from 1987 to 1989 (personal com- munication). In the present report, 22 cases of UC occurring in Chinese patients seen in Vancouver from 1975 to 1989 are reviewed.

\section{PATIENTS AND METHODS}

Medical records were sought retrospectively of all patients of Chinese extraction with an established diagnosis of UC seen in the office from 1975 to 1989 , and in three teaching hospitals and two community hospitals in Vancouver from 1979 to 1989. The records were then reviewed. The diagnosis of UC was based on a compatible history and characteristic sigmoidoscopic, histological and, when available, barium enema and/or colono- scopic findings. In all patients, extensive investigations had been undertaken to exclude intestinal bacterial and parasitic infections.

\section{RESULTS}

Twenty-two patients of Chinese extraction (14 males and eight females) were diagnosed with UC in Vancouver between 1975 and 1989 . The age range at diagnosis was 14 to 67 years (mean 38.9). Table 1 shows epidemiological data for all 22 patients. Ten patients were born in China, nine in Hong Kong and three in Canada. Thirteen patients had lived in Hong Kong before emigrating to Canada, two in China, and one in each of Taiwan, England and India; one patient was a visitor from Hong Kong. The three Canadianborn patients had never resided in a foreign country. The 18 immigrants had lived in Canada for a mean of 9.3 years before they developed symptoms of UC.

The clinical features of the $22 \mathrm{pa}$ tients are shown in Table 2. In 16 patients observed for one to 13 years, the course of the disease was similar to that of Caucasian patients. The disease was limited to the rectum or rectosigmoid region in 13 patients. One patient had segmental resection for a sigmoid carcinoma; none of the patients had colectomy for UC. Of the extraintestinal manifestations of the disease, three patients had arthralgias, one had possible arthralgias and iritis, one had ankylosing spondylitis and one had erythema nodosum.

\section{DISCUSSION}

In a previous report, we detailed our experience with Crohn's disease in the Chinese population of Vancouver (14). This report further describes our experience with inflammatory bowel disease in Chinese patients from Vancouver, specifically with UC. Some features of our Chinese patients and their disease were intriguing. First, the predominance of males reported here is compatible with that of a previous study of Chinese patients in Hong Kong (2). This contrasts with the Canadian experience in nearby Alberta (since no data are available in British Columbia); in 
TABLE 2

Clinical features

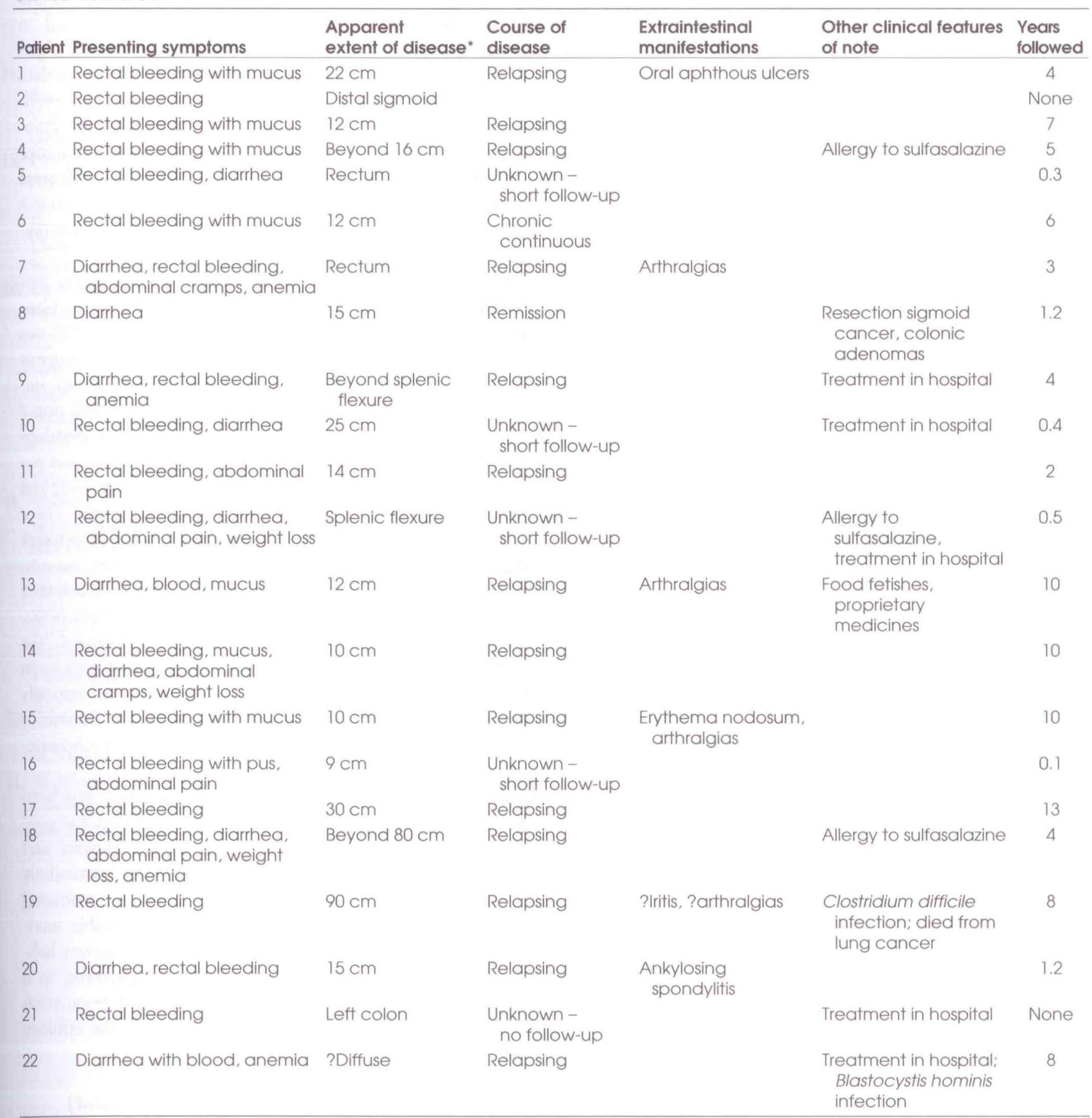

Apparent maximum extent of disease from anal verge

both northern and southern Alberta, prevalence rates of $U C$ were similar in males and females $(15,16)$. Our observations in this Oriental population also contrasts with patients of Anglo-Saxon descent worldwide where the disease has a female preponderance (10).

Second, a limited form of colitis was generally seen in our Chinese patients.
In 13 of the 22 patients (59\%) surveyed in this study, the disease was localized to the rectum or extended to the distal few centimetres of the sigmoid colon. Although the duration of the follow-up in our report is less than 10 years in most of the patients, this limited form of disease appears to be more common in the Chinese than that usually re- ported (17). Moreover, only one patient in our population group had a history of a segmental resection for sigmoid carcinoma and, to date, none of the 22 patients has required a colectomy for UC. The limited extent of disease observed, rarity of complications such as cancer and the limited requirement for early surgical intervention 
suggest that UC may be a milder disease in the Chinese population. Although a longer period of follow-up may help to confirm this initial clinical impression, patients with few symptoms or 'subclinical' disease may not be presenting to subspecialty physicians. As a result, UC may be even more common in the Chinese population of Vancouver than is suggested here.

The causes of UC remain unknown. Epidemiological studies have shown marked regional variations in disease distribution. It is most frequent in North America and northwestern Europe, and less common in southern and eastern Europe (18-21). It is infrequent in Asia, Africa and South America $(19,20)$, even allowing for the difficulties in diagnosis due to a scarcity of medical resources and possible confusion with the infective dysenteries that are prevalent in underdeveloped regions (22). Nevertheless, there have been reports of UC in several Asian populations (1-6,8,9,23-27). There have also been reports of inflammatory bowel disease occurring in Asian immigrant populations in Canada $(11,14$, 28 ) and Great Britain (29-31). However, apart from our initial presentation (11) there has been no other report of UC in the Chinese populations of North America and Europe, areas with the highest incidence rates of the disease in the world.

The variability in the incidence of UC among different ethnic groups from the same geographical regions suggests a genetic predisposition to the disease. $\mathrm{UC}$ is three to five times more common in Jewish people compared with AngloSaxon populations living in western

\section{REFERENCES}

1. Fung WP, Monteiro EH, Murugasu JJ, $\mathrm{Ng}$ KC, Kho KM, Lee SK

Non-specific ulcerative colitis in Chinese and Indians in Singapore. Med J Aust 1971;2:361-5.

2. Lai CL, Wu PC, Wong KL, Lok ASF. Clinical features of ulcerative proctocolitis in Hong Kong Chinese: A review of three decades. Am J Proctol Gastroenterol Colon Rectal Surg 1985;1:14-9.

3. Sung JY, Chan KL, Hsu R, Liew CT, Lawton JWM. Ulcerative colitis and antineutrophil cytoplasmic antibodies in Hong communities (18). UC is rare in the Black population in South Africa (32) and in the Maoris in New Zealand (33), in contrast to the Caucasian populations residing in those countries. In Israel, the incidence and prevalence in the Arab population were markedly lower than those in the Jewish population $(34,35)$. In India, UC occurs more frequently in Hindus than in Muslims, Christians or Parsees (21). In Malaysia, Indians (especially Sikhs) appeared to be more prone to the disease than Chinese and Malays (5). Similarly, in Vancouver, the disease seems to be more common in Asian Indians than Chinese (28).

As in the series of patients with Crohn's disease (14), the majority of patients (14 of 22) in this study immigrated from Hong Kong. In the 1986 national population census from Statistics Canada (13), Hong Kong was listed as the birthplace among $22,275 \mathrm{Chi}$ nese living in Vancouver. This represented $22 \%$ of the total Chinese population of 100,340 in metropolitan Vancouver. The high proportion of Hong Kong immigrants in the present series of patients suggests that, within the Vancouver Chinese community, there is an apparently increased predisposition to develop UC. The reason for this susceptibility is unknown. It is also of interest that in the Vancouver Chinese population, our previously reported experience with Crohn's disease (14) is similar to that with UC.

There are epidemiological data of UC in Canada reported from northern and southern Alberta $(15,16,36)$ but the incidence and prevalence of the disease in British Columbia have not

Kong Chinese. Am J Gastroenterol 1993;88:864-9.

4. Ti TK. Inflammatory diseases of the bowel: A Malaysian experience. Aust N Z J Surg 1979;49:428-31.

5. Thein-Htut, Kudva MV. Ulcerative colitis in Malaysians: A review of 23 patients. Sing Med J 1989;30:385-7.

6. Tan CC, Kang JY, Guan R, Yap I, Tay HH. Inflammatory bowel disease: An uncommon problem in Singapore. J Gastroenterol Hepatol 1992; 7:360-2.

7. Lee SK. Crohn's disease in Singapore. Med J Aust 1974; 1:266-9

8. Ng HS. Chronic inflammatory bowel yet been determined. The mean prevalence rate of $\mathrm{UC}$ in northern Alberta was 37.2 per 100,000 (15) and in southern Alberta was 21.7 per 100,000 (16). Although precise data for British Columbia are not available, these data from Alberta compare with the estimated prevalence rate of 22 per 100,000 in our Chinese population and indicate that UC is not as rare in Chinese as had been previously perceived.

Three of the 22 patients in the present study were born and raised in Canada. Their age at diagnosis of UC was distinctly younger than the mean age at diagnosis of the immigrant group. Immigrants had lived in Canada for a mean of 9.3 years before first developing symptoms of the disease. One patient was a visitor from Hong Kong and was not included in this group. These observations suggest that a time factor may be important in the exposure to one or more exogenous risk factors that could influence the pathogenesis of UC. Moreover, the disparity between the prevalence of UC in the Chinese in Hong Kong and Vancouver strongly supports the influential role of environmental determinants in the pathogenesis of UC.

In the past decade, there has been substantial migration of Chinese people from Hong Kong, Taiwan and China to North America, particularly Vancouver. This offers a continuing opportunity to explore possible environmental factors, such as dietary habits (37) and other life patterns, in a defined ethnic immigrant population that may provide clues to the etiology and pathogenesis of UC.

diseases in Singapore. Sing Med J 1989;30:32-3.

9. Song G. Clinical analysis of 60 cases of ulcerative colitis treated with Chinese traditional medicinal herbs. Chin J Integrated Traditional West Med 1985;5:451.

10. Mendeloff AI. Epidemiologic aspects of inflammatory bowel disease. In: Berk JE, ed. Bockus Gastroenterology, 4th edn. Philadelphia: WB Saunders Company, 1985:2127-36.

11. Chaun H, Freeman HJ. Ulcerative colitis in Chinese in Vancouver, Canada. J Gastroenterol Hepatol 1989;4(Suppl 3):43. (Abst 86) 
12. Calkins BM, Mendeloff AI. Epidemiology of inflammatory bowel disease. Epidemiol Rev 1986;8:60-91.

13. Statistics Canada. 1986;Catalogue no. 93-156.

14. Chaun H, Freeman HJ. Crohn's disease in Chinese people in Vancouver, British Columbia. Can J Gastroenterol 1993;7:28-32.

15. Pinchbeck BR, Kirdeikis J, Thomson ABR. Epidemiology of ulcerative colitis and Crohn's disease. In: Freeman HJ, ed. Inflammatory Bowel Disease, vol 1. Boca Raton: CRC Press Inc, 1989:9-35.

16. Davis FG, Grace MG, Hershfield N. Inflammatory bowel disease incidence and prevalence in southern Alberta. Can J Gastroenterol 1990;4:187-92.

17. Roth JLA. Ulcerative colitis. In: Bockus HL, ed. Gastroenterology, vol II, 3rd edn. Philadelphia: WB Saunders Company, 1976:645-749.

18. Mayberry JF. Some aspects of the epidemiology of ulcerative colitis. Gut 1985;26:968-74.

19. Mendeloff AI, Calkins BM. The epidemiology of idiopathic inflammatory bowel disease. In: Kirsner JB, Shorter RG, eds. Inflammatory Bowel Disease, 3rd edn. Philadelphia: Lea and Febiger, 1988:3-34.

20. Whelan G. Epidemiology of inflammatory bowel disease. Med Clin North Am 1990;74:1-12.

21. Mayberry JF. Recent epidemiology of ulcerative colitis and Crohn's disease. Int J Colorectal Dis 1989;4:59-66.

22. Chuttani HK, Nigam SP, Sama SK, Dhanda PC, Gupta PS. Ulcerative colitis in the tropics. Br Med J 1967;4:204-7.

23. Yoshida Y, Murata Y. Inflammatory bowel disease in Japan: Studies of epidemiology and etiopathogenesis. Med Clin North Am 1990;74:67-90.

24. Tandon BN, Mathur AK, Mohapatra LN, Tandon HD, Wig KL. A study of the prevalence and clinical pattern of non-specific ulcerative colitis in northern India. Gut 1965;6:448-53.

25. Probert CSJ, Mayberry JF, Mann R. Inflammatory bowel disease in the rural Indian subcontinent: a survey of patients attending mission hospitals. Digestion 1990;47:276-80

26. Kochar R, Ayyagari A, Goenka MK, Dhali GK, Aggarwal R, Mehta SK.

Role of infectious agents in exacerbations of ulcerative colitis in India. A study of Clostridium difficile. J Clin Gastroenterol 1993;16:26-30.

27. Quereshi H, Zuberi SJ, Banatwala N, Anwar A, Shamsi Z, Khan MN.

Ulcerative colitis in Karachi. J Gastroenterol Hepatol 1989;4:313-6.

28. Chaun H, Freeman HJ, Owen DA. Idiopathic inflammatory bowel disease in patients of Asian Indian ancestry in Vancouver, Canada. The World Congress of Gastroenterology, Sydney, Australia. Abstracts I. 1990:717. (Abst)

29. Das SK, Montgomery RD. Chronic inflammatory bowel disease in Asian immigrants. Practitioner 1978;221:747-9.

30. Benfield GFA, Montgomery RD, Asquith P. Ulcerative colitis in Asian immigrants. Postgrad Med J 1987;63:629-35.

31. Probert CSJ, Jayanthi V, Pinder D, Wicks AC, Mayberry JF.

Epidemiological study of ulcerative proctocolitis in Indian immigrants and the indigenous population of Leicestershire. Gut 1992;33:687-93.

32. Segal I, Tim LO, Hamilton DG Walker ARP. The rarity of ulcerative colitis in South African Blacks. Am J Gastroenterol 1980;74:332-6.

33. Wigley RD, Maclaurin BP. A study of ulcerative colitis in New Zealand showing a low incidence in Maoris. Br Med J 1962;2:228-31.

34. Odes HS, Fraser D, Krugliak P, Fenyves D, Fraser GM, Sperber AD. Inflammatory bowel disease in the Bedouin Arabs of southern Israel: rarity of diagnosis and clinical features. Gut 1991;32:1024-6.

35. Niv Y, Torten D, Tamir A, Epstein L. Incidence and prevalence of ulcerative colitis in the Upper Galilee, Northern Israel, 1967-1986. Am J Gastroenterol 1990;85:1580-3.

36. Pinchbeck BR, Kirdeikis J, Thomson ABR. Inflammatory bowel disease in northern Alberta. An epidemiologic study. J Clin Gastroenterol 1988;10:505-15.

37. O'Morain C, Tobin A, Suzuki Y, O'Riordan T. Risk factors in inflammatory bowel disease. Scand J Gastroenterol 1989;24:58-60. 


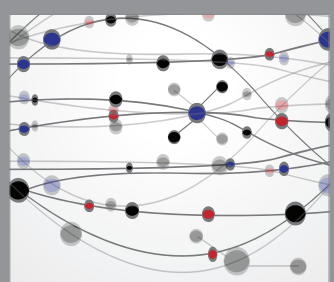

The Scientific World Journal
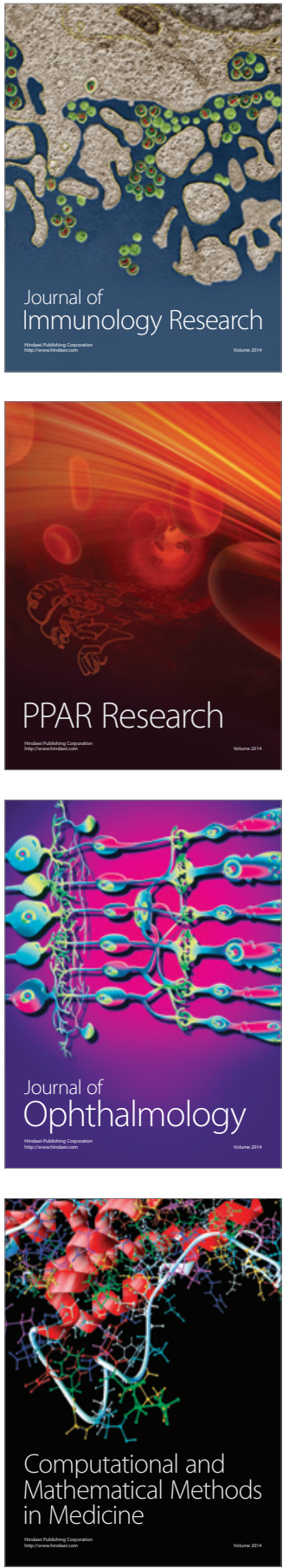

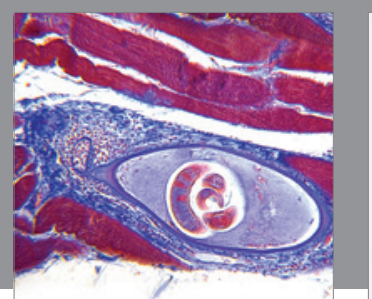

Gastroenterology Research and Practice

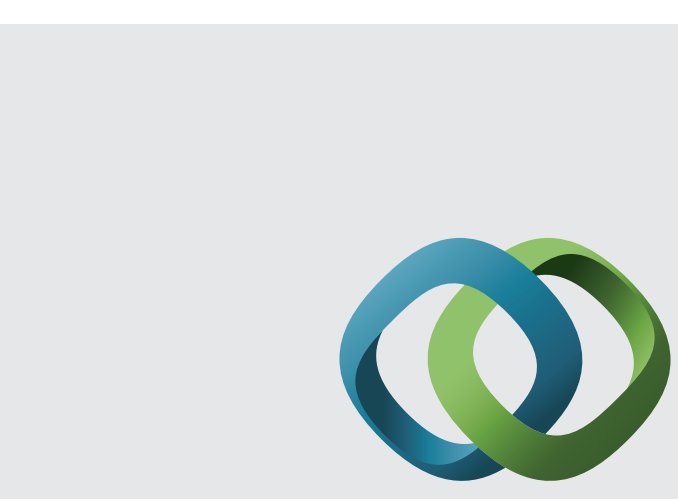

\section{Hindawi}

Submit your manuscripts at

http://www.hindawi.com
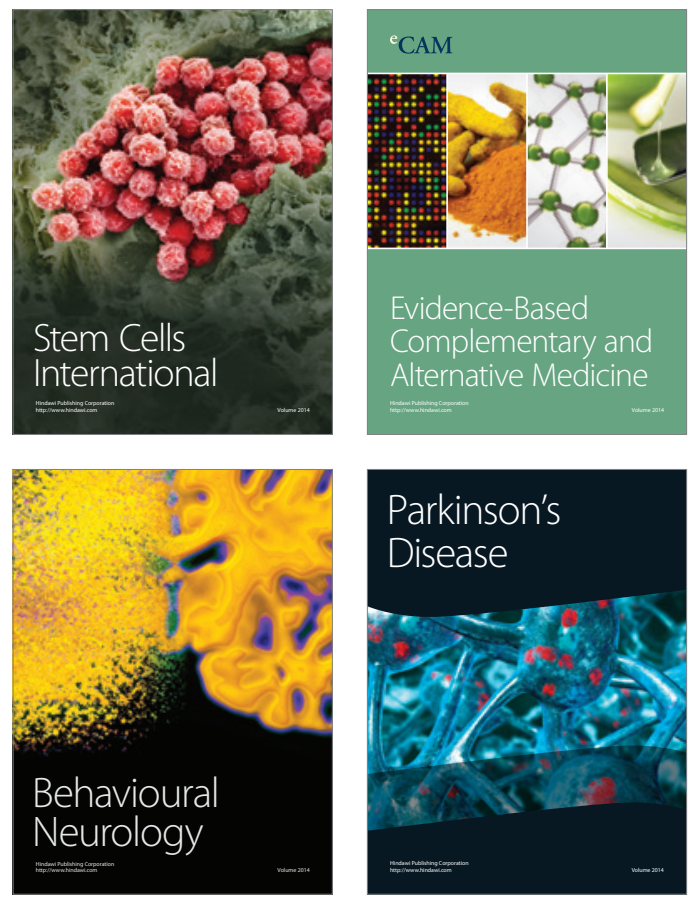
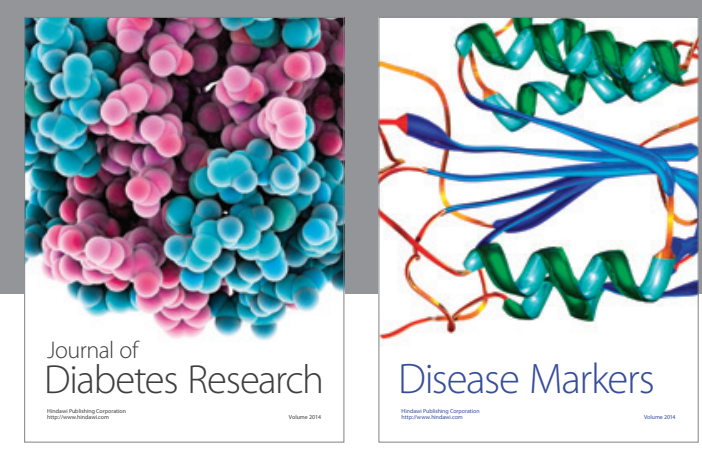

Disease Markers
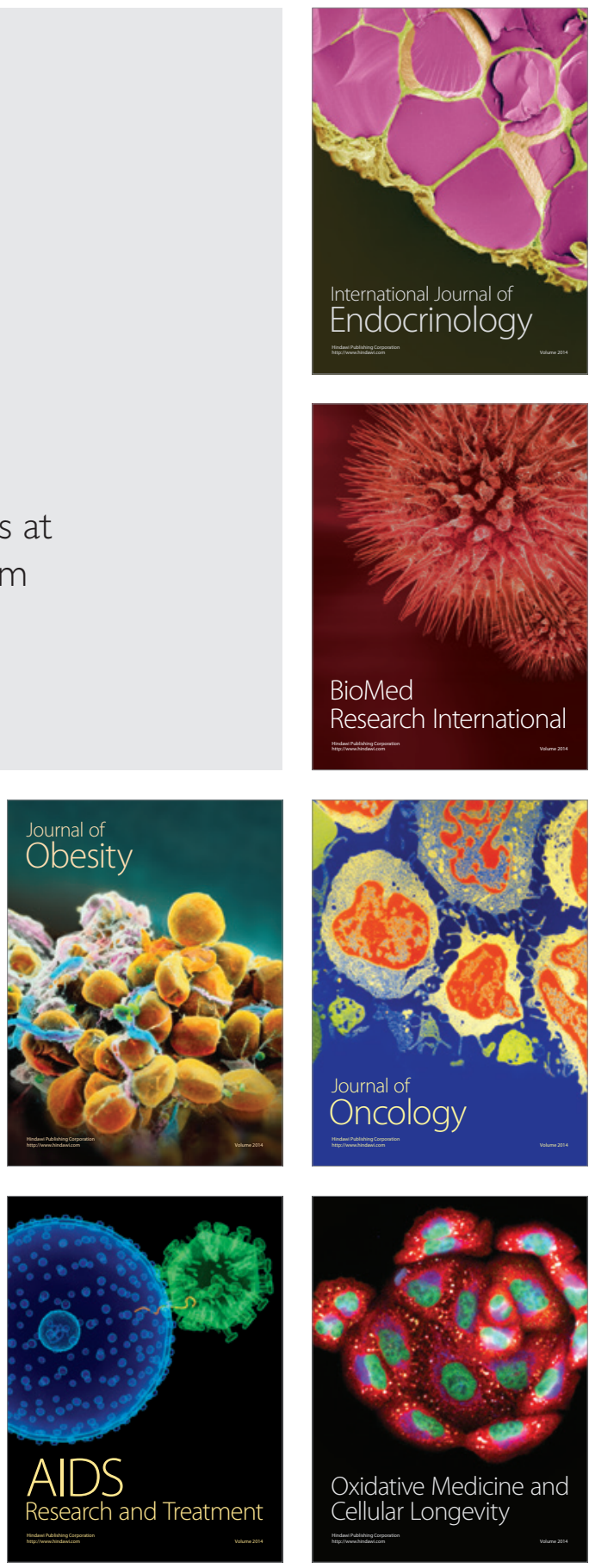